\title{
Ear, nose and throat (ENT) involvement in zoonotic diseases: a systematic review
}

\author{
Bruno Galletti ${ }^{1}$, Valentina K. Mannella ${ }^{1}$, Roberto Santoro ${ }^{1}$, Alfonso J. Rodriguez-Morales ${ }^{2,3}$ Francesco $^{3}$ \\ Freni $^{1}$, Claudio Galletti ${ }^{4}$, Francesco Galletti ${ }^{1}$, Antonio Cascio ${ }^{3,5}$ \\ ${ }^{1}$ Otorhinolaryngology Unit Department of Surgical Specialities, University Hospital G. Martino, Messina, Italy \\ ${ }^{2}$ Faculty of Health Sciences, Universidad Tecnológica de Pereira, Pereira, Risaralda, Colombia. Comité de \\ Zoonosis y Fiebres Hemorrágicas, Asociación Colombiana de Infectología (ACIN) \\ ${ }^{3}$ Working Group on Zoonoses, International Society for Chemotherapy \\ ${ }^{4}$ Department of Neurosciences, Psychiatric and Anesthesiological Sciences, University of Messina, Italy \\ ${ }^{5}$ Tropical and Parasitological Diseases Unit, Department of Human Pathology, Policlinico G. Martino, Messina, Italy
}

\begin{abstract}
Introduction: Zoonoses are infections transmitted from animal to man, either directly (through direct contact or contact with animal products) or indirectly (through an intermediate vector, such as an arthropod). The causative agents include bacteria, parasites, viruses, and fungi. The purpose of this review is to make an accurate examination of all zoonotic diseases that can be responsible of ear, nose, and throat (ENT) involvement.

Methodology: A PubMed search was performed combining the terms (otorhinolaryngology OR rhinology OR laryngology OR otology OR mastoiditis OR otitis OR sinusitis OR laryngitis OR rhinitis OR pharyngitis OR epiglottitis OR dysphonia OR ear OR larynx OR nose OR pharynx) with each one of the etiological agents of zoonoses for the period between January 1997 and August 2012 without language restrictions.

Results: A total of 164 articles were selected and examined. Larynx was the most commonly involved ENT organ, followed by oral cavity, pharynx, and neck. Bacteria were the most representative microorganisms involved. Nose and major salivary glands were affected most frequently by protozoa; paranasal sinus, oral cavity, ear, neck, nerves and upper airway by bacteria; and larynx by fungi.

Conclusions: ENT symptoms and signs may be present in many zoonotic diseases, some of which are also present in industrialized countries. Most zoonotic diseases are not commonly encountered by ENT specialists. Appreciation of the possible occurrence of these diseases is important for a correct microbiological approach, which often requires special culture media and diagnostic techniques.
\end{abstract}

Key words: ENT; zoonoses; otorhinolaryngology

J Infect Dev Ctries 2014; 8(1):017-023. doi:10.3855/jidc.4206

(Received 03 September 2013 - Accepted 02 December 2013)

Copyright $(92014$ Galletti et al. This is an open-access article distributed under the Creative Commons Attribution License, which permits unrestricted use, distribution, and reproduction in any medium, provided the original work is properly cited.

\section{Introduction}

Although zoonotic infections are a major burden worldwide - both in terms of immediate and long-term morbidity and mortality [1,2] and in terms of socioeconomical, ecological, and political impact [3] scientific and public health interest and funding for these diseases remain relatively minor and inadequate [4]. Zoonotic infections are defined, in general, as infections transmitted from animal to man (and, less frequently, vice versa), either directly (through direct contact or contact with animal products) or indirectly (through an intermediate vector, such as an arthropod) [5]. Zoonotic disease may affect ENT districts. Unfortunately, literature is often limited to single case reports from different countries and does not allow adequate appreciation of the problem. Otorhinolaryngologists often lack in-depth knowledge of zoonotic diseases, which complicates etiological identification and treatment and control strategies. In the present review, we summarized scientific publications on zoonotic diseases that directly or indirectly involved the ENT area.

\section{Bibliographical research}

A PubMed Medline search for human cases of zoonotic diseases involving head and neck areas was performed combining the terms (otorhinolaryngology OR rhinology OR laryngology OR otology OR mastoiditis OR otitis OR sinusitis OR laryngitis OR rhinitis OR pharyngitis OR epiglottitis OR dysphonia 
Figure 1. Anatomical localization of zoonotic agents at ENT region.

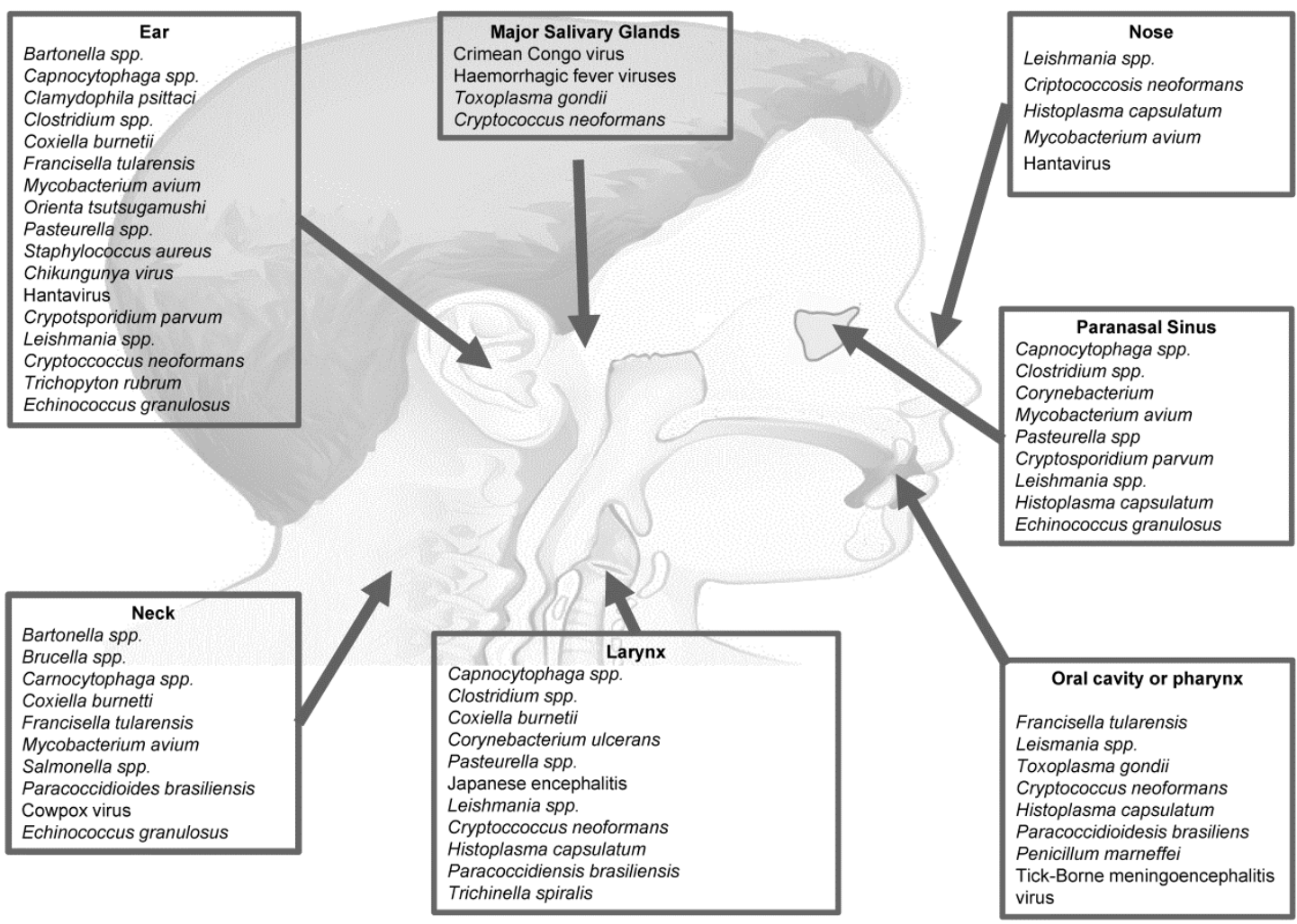

OR ear OR larynx OR nose OR pharynx) with each one of the etiological agents of zoonoses indicated in Tables 1-4 for the period between January 1997 and August 2012 without language restrictions. A study was considered eligible for inclusion in the systematic review if it reported data on patients with zoonotic diseases who presented ENT signs and/or symptoms. Duplicate publications or papers not reporting clinical cases were excluded. The inclusion criteria were applied and the data were extracted by one reviewer and then checked by a second reviewer.

\section{Results}

After a scrupulous analysis, 164 papers were considered and examined. Most of the papers are listed on the basis of the etiological agent in Tables 1-4, and a brief note was reported for each paper if it was considered relevant.

Nasal involvement was found in 24 papers. Most of the studies reported cases of leishmaniasis and fungal infections (Tables 3 and 4); bacterial diseases were reported in two articles, and one case each of Hantavirus and echinococcosis was also reported (Tables 2 and 4). Common symptoms were nose bleeding and other symptoms resulting from inflammatory pseudotumor (Figure 1).
Paranasal sinus involvement, commonly with sinusitis symptoms, was described in 13 articles. The etiological agents in seven articles were bacteria; protozoa, fungi, and helminths were each the etiological agents in two articles (Figure 1).

Involvement of the oral cavity or pharynx was found in 41 papers. Bacteria (in most of the cases, Francisella tularensis reported from Turkey) were detected as agents of these conditions in 25 articles (Table 1), followed by protozoa (eight articles), fungi (seven articles), and viruses. Pharyngitis, tonsillitis, pharyngotonsillitis, and dysphagia were found frequently, often associated with lymphadenopathy and fever (Figure 1).

Involvement of the larynx was described in 39 articles. Bacteria were the etiologic agents in eight articles, the Japanese encephalitis virus was the etiologic agent in one article, Leishmania spp in 11 articles (Table 4), fungi in 18 articles (Table 3), and helminths in one article (Table 4). Symptoms of larynx involvement were epiglottitis, dysphonia, or dyspnea (Figure 1).

Thirty-five articles documented ear involvement. Bacteria were identified in 21 articles (Table 1), viruses in four (Table 2), protozoa in one (Table 4), fungi in four (Table 3), and helminths in one article 
(Table 4). Otitis media, otomastoiditis, sensorineural loss of hearing, and vestibular dysfunction were the most frequently reported conditions (Figure 1).

Involvement of the neck was found in 33 articles. Bacteria were identified in 29 articles, fungi in two articles, viruses (Cowpox virus) in one article, and helminths (Echinococcus granulosus) in one article. The most frequent manifestation was lymphadenopathy. Rarely, retropharyngeal or neck abscess and necrotizing fasciitis were found (Figure 1).

Nerve disease was described in eight articles. The most frequently involved agents were bacteria: Bartonella henselae, Borrelia burgdorferi, and Campylobacter spp. in one case (Table 1), West Nile Virus in one case (Table 2), and Leishmania spp. were detected in one case (Table 4). The most frequent manifestation was facial or laryngeal nerve paralysis.

An involvement of the total upper airway was found in three papers, each one reporting cases of infection with Clostridium botulinum, Mycobactrium avium, and Corynebacterium ulcerans (Table 1). Only one article documented an involvement of facial tissue in the course of helminthiasis (dirofilariasis) (Table 4).

Involvement of major salivary glands was found in four articles. Etiologicals agents were in one case Crimean-Congo haemorrhagic fever virus, in two cases Toxoplasma gondii, and in one case Cryptococcus neoformans. Symptoms were parotitis or parotid mass (Figure 1).

Table 1. Bacterial agents of zoonoses and ENT manifestations

\begin{tabular}{|c|c|}
\hline Bacteria & [References] ENT manifestations and notes \\
\hline Bartonella spp. & $\begin{array}{l}\text { [6] Atypical presentations of cat scratch disease in the head and neck; cat scratch disease presenting as acute } \\
\text { mastoiditis; neck abscess secondary to cat-scratch disease; traveler's fever, cervical adenomegaly, Brazilian } \\
\text { patient returning from South Africa; cat scratch disease presenting with peripheral facial nerve paralysis. }\end{array}$ \\
\hline Brucella spp. & $\begin{array}{l}\text { [7] Severe pharyngitis, } 2 \text { cases; [8] isolated cervical lymphadenopathy; }[9,10] \text { infection of a branchial cyst; } \\
\text { [11] paravertebral abscess, torticollis; [12] Brucellar spinal epidural abscess compressing the retropharyngeal } \\
\text { space. }\end{array}$ \\
\hline Campylobacter spp. & [13] Multiple cranial neuropathy; [14] oropharyngeal palsy with nasal voice. \\
\hline Capnocytophaga spp. & $\begin{array}{l}\text { [15] Sudden sensorineural hearing loss; [16] C. sputigena primary iliopsoas abscess secondary to } \\
\text { haematogenous spread from a palatal fistula and chronic sinusitis due to previous treatment for } \\
\text { nasopharyngeal carcinoma; [17] epiglottitis and necrotizing fasciitis (complication of infectious } \\
\text { mononucleosis); [18] retropharyngeal abscess, } 2 \text { cases. }\end{array}$ \\
\hline Chlamydophyla psittaci & [19] Sudden sensorineural hearing loss. \\
\hline Clostridium spp. & $\begin{array}{l}\text { [20]Botulism and dysphagia; [21] diplopia with tonsillitis; [22] infant botulism, retrospective study, } 60 \text { cases, } \\
\text { infant, Brazil; [23] otogenic tetanus; [24] otogenic tetanus in children; [25] C. perfringens, sphenoid sinusitis; } \\
\text { [26] C. perfringens, fatal acute necrotizing tonsillitis; [27] brain abscess secondary to acute otomastoiditis; } \\
\text { [18] C. glycolicum, otogenic brain abscesses. }\end{array}$ \\
\hline Coxiella burnetii & [28] Otological manifestations; fever, bilateral tonsillitis, spiking fever, lymphadenopathy, and laryngitis. \\
\hline $\begin{array}{l}\text { Corynebacterium } \\
\text { ulcerans }\end{array}$ & $\begin{array}{l}\text { [29] Diphtheria, France, Japan, the Netherlands, Indiana,USA; fatal case of necrotizing sinusitis, Germany; } \\
\text { [30] laryngopharyngitis, Switzerland. }\end{array}$ \\
\hline Francisella tularensis & $\begin{array}{l}\text { [31] Oropharyngeal, Serbia; [32] parapharyngeal abscess, Turkey; outbreak of oropharyngeal } \\
\text { tularemiaTurkey; neck mass, } 33 \text { patients; oropharyngeal tularemia, Germany; [33] otitis media, suppurative } \\
\text { lymphadenopathy, retropharyngeal abscess, Germany; otitis media, Finland; water-borne outbreak of } \\
\text { oropharyngeal and glandular tularemia, Georgia; 12-case outbreak, consumption of camel meat, Jordan. }\end{array}$ \\
\hline acterium avium, & [34] M. avium-intracellulare, sinusitis, 8 patients; [35] M. avium-intracellulare sinusitis; M. avium \\
\hline $\begin{array}{l}\text { M. marinum, } M \text {. } \\
\text { malmoense }\end{array}$ & $\begin{array}{l}\text { intracellulare otomastoiditis; } M \text {. avium complex, cervical lymphadenitis, } 8 \text { cases); M. avium intracellulare, } \\
\text { pseudotumor of the anterior nasal cavity; disseminated } M \text {. avium infection, immunocompetent aged patient; } \\
\text { nasal fish tank granuloma, epistaxis; } M \text {. malmoense, laryngitis. }\end{array}$ \\
\hline Orientia tsutsugamushi & $\begin{array}{l}\text { [36] Otalgia and eschar in the external auditory canal in scrub typhus complicated by acute respiratory distress } \\
\text { syndrome and multiple organ failure. }\end{array}$ \\
\hline Pasteurella spp. & $\begin{array}{l}\text { [37] } P \text {. multocida, fatal case, epiglottitis; } P \text {. haemolytica, croup; contamination of post-endoscopic sinus } \\
\text { surgery sinus cavities with } P \text {. multocida, Canada; invasive } P \text {. multocida sinusitis, renal transplant patient; } P \text {. } \\
\text { multocida, chronic purulent otorrhoea, meningitis transmitted by a dog that frequently licked his ear; } P \text {. } \\
\text { multocida, acute bacterial meningitis, otitis media. }\end{array}$ \\
\hline Salmonella spp. & 8] S. lomita retropharyngeal abscess; neck abscess, diabetes mellitus, 2 patients; $S$. senftenberg, otitis media \\
\hline
\end{tabular}

(excluding S. typhi)

Staphylococcus aureus

(clearly associated to

animal reservoir)
[39] Destructive otomastoiditis by MRSA from porcine origin, Belgium. 
Table 2. Viral agents of zoonoses and ENT manifestations

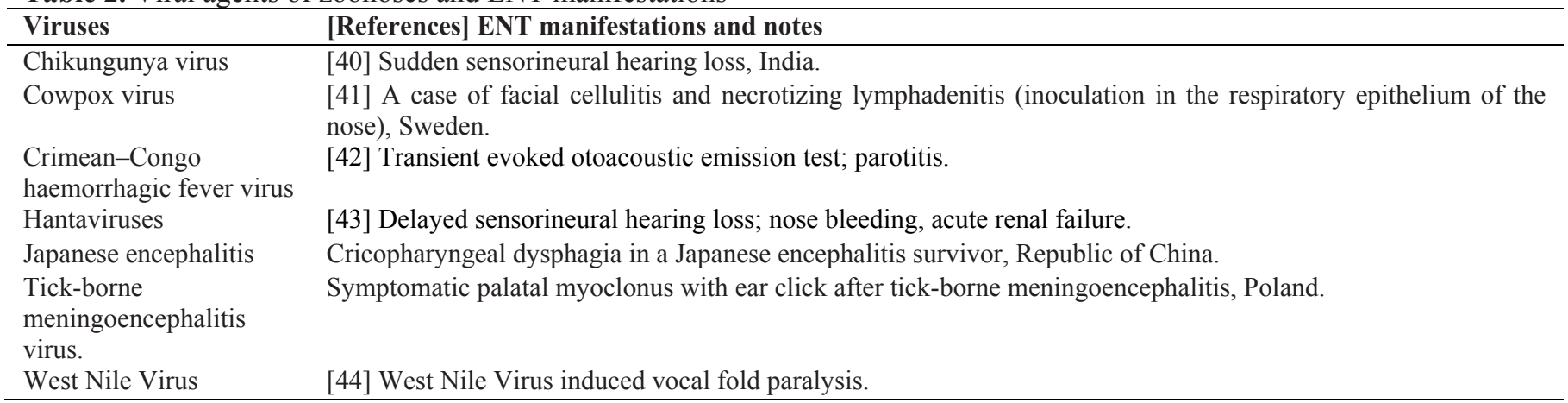

Table 3. Parasite agents of zoonoses and ENT manifestations

\begin{tabular}{|c|c|}
\hline Parasite groups & [References] ENT manifestations and notes \\
\hline \multicolumn{2}{|l|}{ Protozoa } \\
\hline \multirow[t]{6}{*}{ Leishmania spp. } & Mucosal leishmaniasis, 140 patients, Brazil. \\
\hline & $\begin{array}{l}\text { [47] A chronic mutilating rhinopathy,India; laryngeal involvement, post kala-azar dermal leishmaniasis } 3 \text { cases, } \\
\text { India; isolated laryngeal leishmaniasis in an immunocompetent patient in India; ulcerative post-kala azar }\end{array}$ \\
\hline & $\begin{array}{l}\text { Lebanon; endonasal, L. infantum MON-80, Tunisia; [48] immunocompromised patient, ulcerated nasolabial } \\
\text { skin lesion, Greece; [49] L. infantum MON-111 endonasal leishmaniasis, } 2 \text { cases, Italy; [50] laryngeal }\end{array}$ \\
\hline & $\begin{array}{l}\text { leishmaniasis, immunocompetent, Malta; nasal cavity, UK; [51] laryngeal leishmaniasis, three cases, Spain; } \\
\text { acute tonsillitis, immunocompetent, Greece; laryngitis, long term steroid inhaler use, UK; systemic }\end{array}$ \\
\hline & leishmaniasis involving the nose, Belgium; epiglottis involvement in a visceral leishmaniasis, France; [52] \\
\hline & nasal, AIDS, Spain; tongue (history of treated laryngeal leishmaniasis), AIDS, Spain; [53] oral, HIV-infected, \\
\hline \multicolumn{2}{|l|}{ Helminths } \\
\hline Trichinella spiralis & Trichinella spiralis, laryngeal carcinoma. \\
\hline Echinococcus granulosus & Maxillary sinus; neck; otogenic brain absces. \\
\hline Dirofilaria spp. & Paranasal sinuses; facial mass. \\
\hline
\end{tabular}

Table 4. Fungal agents of zoonoses and ENT manifestations

\begin{tabular}{|c|c|}
\hline Fungi & [References] ENT manifestations and notes \\
\hline Cryptococcus & [58] Tongue, Malaysia; retropharyngeal abscess; laryngitis, AIDS; vocal cord cyst; laryngitis simulating \\
\hline Histoplasma capsulatum & $\begin{array}{l}\text { [59] Sinusitis, AIDS; sinusitis, chronic lymphocytic leukemia; oropharyngeal, Brazil, } 11 \text { cases (5 AIDS); oral, } \\
\text { HIV-negative patient, Brazil; oral histoplasmosis, } 31 \text { cases ( } 21 \text { AIDS), Argentina; nasal septum, AIDS; nasal, } \\
\text { immunocompetent, India; laryngitis, AIDS, Argentina; epiglottic histoplasmosis. }\end{array}$ \\
\hline Penicillium marneffei & Pharyngeal tumor, AIDS, China. \\
\hline Trichophyton spp. & Trichophyton rubrum, external auditory meatus. \\
\hline
\end{tabular}


Cases occurring in HIV-infected patients were reported in leishmaniasis, cryptococcosis, histoplasmosis, and penicillinosis. Other immunosoppressive factors (malignancy, leukemia, solid organ transplant, steroids) were found in patients with criptococcosis, leishmaniasis, pasteurellosis, histoplasmosis, penicillinosis, and trichinellosis.

Five papers described cases occurring in travelers: two cases of leishmaniasis (Table 4), and a case each of paracoccidioidomycosis, histoplasmosis (Table 3), and bartonellosis (Table 1). Some cases were complicated by severe symptoms and death. Some papers reported cases in which the zoonotic lesions could have been misdiagnosed as cancer. These included three cases of leishmaniasis (Table 4), a case of laryngeal criptococosis (Table 3), two cases of laryngeal paracoccidiomicosis (Table 3 ), and one case of toxoplasmosis lymphadenitis presenting as a parotid mass (Table 4).

\section{Discussion}

On the basis of the present review, the larynx seem to be the most common ENT organ involved in zoonotic diseases, followed by the oral cavity, pharynx, and neck. Bacteria were the most frequently involved agents [6-39]. The nose and major salivary glands seemed to be affected most frequently by protozoa [47-49]; paranasal sinus, oral cavity, ear, neck, nerves, and upper airway were most affected by bacteria, and the larynx was most affected by fungi [58-60].

Of all the microorganisms considered, some have a worldwide distribution, while others are restricted to certain geographic areas. Mucosal leishmaniasis is uncommon outside of Central and South America. Mucosal leishmaniasis contracted in southern Europe mostly affected adult males, of which half were immunodeficient. Clinical polymorphism makes diagnosis difficult.

It is important to note that the ENT manifestations in some zoonoses can be an integral part of the disease - for example, American mucocutaneous leishmaniasis (ACL) [46-56] and botulism - while in others, such as paracoccidiomicosis or tularemia, ENT involvement is only occasionally found. In addition, many diseases that usually do not produce ENT involvement (such as histoplasmosis, leishmaniasis of the Mediterranean region, and criptococcosis) can produce it in immunosuppressed patients. Histoplasmosis, an AIDS-defining disease, may present as a disseminated form in which oral lesions are found in $30 \%$ to $50 \%$ of patients.
The present work shows that ENT symptoms and signs may be present in many zoonotic diseases, some of which are also present in industrialized countries. Most of these diseases are not commonly encountered by ENT specialists who may confuse them occasionally for neoplastic conditions. Appreciation of the possible occurrence of these diseases is important for a correct microbiological approach, which often requires special culture media and diagnostic techniques.

Zoonotic diseases may be difficult to diagnose and can be capable of confusing even the most experienced physicians, especially if they occur in countries where the disease is not endemic. Because there are no common signs and symptoms of zoonotic diseases involving ENT districts, the practicing otorhinolaringologist, while attending to patients with ENT symptoms not responding to common therapy, should pay particular attention to anamnesis (immunosuppressive therapy; history of at-risk professional and recreational occupations such as hunter, ranger, farmer, and veterinarian; recent travel to endemic regions; particular environment of life of the patients and their partners; and eating habits) and consider the possibility of a zoonotic disease $[3,4]$.

From the dawn of modern medicine, the understanding of infectious disease and how to treat it has been an integral part of the physician's craft in all fields. Undoubtedly, the impact of zoonotic diseases may vary in relationship to the socioeconomic context and to the public health system in different geographic areas. A greater threat exists in developing countries [3], which today is of utmost importance in the context of globalization. The practice of travel medicine with the possibility of imported cases from endemic regions is also of growing concern. Often, because of economic globalization and increased travel and migration (even forced, as occurs with refugees), agents are found in countries different from their source [61]. Because this may cause serious diagnostic difficulties, it is important that physicians from both endemic and non-endemic zones increase their awareness of diseases that have been previously considered to be uncommon in their home countries. 


\section{References}

1. Christou L (2011) The global burden of bacterial and viral zoonotic infections. Clin Microbiol Infect 17: 326-330.

2. Akritidis N (2011) Parasitic, fungal and prion zoonoses: an expanding universe of candidates for human disease. Clin Microbiol Infect 17: 331-335.

3. Cascio A, Bosilkovski M, Rodriguez-Morales AJ, Pappas G (2011) The socio-ecology of zoonotic infections. Clin Microbiol Infect 17: 336-342.

4. Pappas G, Cascio A, Rodriguez-Morales AJ (2012) The immunology of zoonotic infections. Clin Dev Immunol 2012: 208508.

5. Pappas G (2011) Of mice and men: defining, categorizing and understanding the significance of zoonotic infections. Clin Microbiol Infect 17: 321-325.

6. Chiu AG, Hecht DA, Prendiville SA, Mesick C, Mikula S, Deeb ZE (2001) Atypical presentations of cat scratch disease in the head and neck. Otolaryngol Head Neck Surg 125: 414416.

7. Zachou K, Papamichalis PA, Dalekos GN (2008) Severe pharyngitis in stockbreeders: an unusual presentation of brucellosis. Occup Med (Lond) 58: 305-307.

8. Yilmaz M, Bayazit N, Gurbuzler L, Ercan N, Ceylan A, Bayazit Y (2009) Isolated cervical lympadenopathy: unusual presentation of localised brucellosis. Int J Clin Pract 63: 674675.

9. Rameh C, Hamdan AL, Uwaydah M, Sabra O, Araj G, Fuleihan N (2007) Brucella melitensis infection of a branchial cyst. Otolaryngol Head Neck Surg 136: 1023-1024.

10. Apostolova E, Papadopoulos V, Leptidou-Kerestetzi T (2002) Branchial cyst empyema due to Brucella melitensis infection as a form of focal Brucellosis. J Infect 44: 271.

11. Simsek S, Yigitkanli K, Kazanci A, Belen D, Bavbek M (2007) Medically treated paravertebral Brucella abscess presenting with acute torticollis: case report. Surg Neurol 67: 207-210

12. Pina MA, Ara JR, Modrego PJ, Juyol MC, Capablo JL (1999) Brucellar spinal epidural abscess. Eur J Neurol 6: 87-89.

13. Kobori S, Yoshii F, Takahashi H, Takagi S, Funakoshi K (2007) A case of multiple cranial neuropathy after Campylobacter jejuni infection. Rinsho Shinkeigaku 47: 5355.

14. Wada Y, Yanagihara C, Nishimura Y, Susuki K (2006) A case of acute oropharyngeal palsy with nasal voice as main symptom. No To Shinkei 58: 235-238.

15. Tamura A, Matsunobu T, Kurita A, Shiotani A (2012) Hemophagocytic Syndrome in the Course of Sudden Sensorineural Hearing Loss. ORL J Otorhinolaryngol Relat Spec 74: 211-214.

16. Chan JF, Wong SS, Leung SS, Li IW, To KK, Cheng VC, Yuen KY (2010) Capnocytophaga sputigena primary iliopsoas abscess. J Med Microbiol 59: 1368-1370.

17. Caballero M, Sabater F, Traserra J, Alos L, Bernal-Sprekelsen $M$ (2005) Epiglottitis and necrotizing fasciitis: a lifethreatening complication of infectious mononucleosis. Acta Otolaryngol 125: 1130-1133.

18. Miyazaki T, Ito $\mathrm{Y}$, Kato M, Akita S, Mizuta K, Miyata H, Kato N, Watanabe K (1998) Retropharyngeal abscess in an adult and an elderly woman. Kansenshogaku Zasshi 72: 157161.

19. Brewis C, McFerran DJ (1997) 'Farmer's ear': sudden sensorineural hearing loss due to Chlamydia psittaci infection. J Laryngol Otol 111: 855-857.
20. Mangilli LD, Andrade CR (2007) Botulism and dysphagia. Pro Fono 19: 215-222.

21. Viestenz A, Schoerner C, Mayer U (2003) Diplopia with tonsillitis. Ophthalmologe 100: 744-746.

22. Anderson TD, Shah UK, Schreiner MS, Jacobs IN (2002) Airway complications of infant botulism: ten-year experience with 60 cases. Otolaryngol Head Neck Surg 126: 234-239.

23. Sharma A, Kapoor S (2006) Relapse in a child with otogenic tetanus. Trop Doct 36: 56-57.

24. Bogomol'skii MR, Iakushenkova AP, Ozhano S, Setkhi S (2002) Otogenic tetanus in children. Vestn Otorinolaringol: 53-54.

25. Rosenblum BN, Gutwein M, Bartell MF (2001) Sphenoid sinusitis caused by Clostridium perfringens. Otolaryngol Head Neck Surg 125: 101-102.

26. Gerber JE (2001) Acute necrotizing bacterial tonsillitis with Clostridium perfringens. Am J Forensic Med Pathol 22: 177179.

27. Jimenez-Mejias ME, Del Nozal M, Becceril B, Pichardo C, Polaina M, Arroyo A (2000) Brain abscess caused by Clostridium sp. secondary to acute otomastoiditis. J Infect 40: 294-295.

28. Upile T, Jerjes W, Mahil J (2008) Q fever-related otological manifestations following chronic exposure to products of conception? Br J Dermatol 158: 1389.

29. Aaron L, Heurtebise F, Bachelier MN, Guimard Y (2006) Pseudomembranous diphtheria caused by Corynebacterium ulcerans. Rev Med Interne 27: 333-335.

30. Kaufmann D, Ott P, Ruegg C (2002) Laryngopharyngitis by Corynebacterium ulcerans. Infection 30: 168-170.

31. Djordjevic-Spasic M, Potkonjak A, Kostic V, Lako B, Spasic Z (2011) Oropharyngeal tularemia in father and son after consumption of under-cooked rabbit meat. Scand J Infect Dis 43: 977-981.

32. Koc S, Gurbuzler L, Yaman H, Eyibilen A, Salman N, Ekici A (2012) Tularaemia presenting as parapharyngeal abscess: case presentation. J Laryngol Otol 126: 535-537.

33. Gurkov R, Kisser U, Splettstosser W, Hogardt M, Krause E (2009) Tularaemia of middle ear with suppurative lymphadenopathy and retropharyngeal abscess. J Laryngol Otol 123: 1252-1257.

34. Suh JD, Ramakrishnan VR, Tajudeen B, Reger C, Kennedy DW, Chiu AG (2011) Identification and treatment of nontuberculous Mycobacterium sinusitis. Am J Rhinol Allergy 25: 421-424.

35. Nabi S, Marglani OA, Javer AR (2010) Mycobacterium avium-intracellulare Sinusitis. J Otolaryngol Head Neck Surg 39: E51-55.

36. Lee BJ, Chen CY, Hu SY, Tsan YT, Lin TC, Wang LM (2011) Otalgia and eschar in the external auditory canal in scrub typhus complicated by acute respiratory distress syndrome and multiple organ failure. BMC Infect Dis 11: 79.

37. O'Connell K, Fennell J, Callaghan J, Rowaiye B, Cormican M (2009) A fatal case of Pasteurella multocida epiglottitis. Ir J Med Sci 178: 541-542.

38. Su FH, Chen PT, Chiu YC, Chen JW (2003) Salmonella retropharyngeal abscess in a child: case report and literature review. Pediatr Infect Dis J 22: 833-836.

39. Van Hoecke H, Piette A, De Leenheer E, Lagasse N, Struelens M, Verschraegen G, Dhooge I (2009) Destructive otomastoiditis by MRSA from porcine origin. Laryngoscope 119: 137-140. 
40. Bhavana K, Tyagi I, Kapila RK (2008) Chikungunya virus induced sudden sensorineural hearing loss. Int $\mathrm{J}$ Pediatr Otorhinolaryngol 72: 257-259.

41. Pahlitzsch R, Hammarin AL, Widell A (2006) A case of facial cellulitis and necrotizing lymphadenitis due to cowpox virus infection. Clin Infect Dis 43: 737-742.

42. Engin A, Yildirim A, Kunt T, Bakir M, Dokmetas I, Ozdemir L (2008) Clinical investigation of the transient evoked otoacoustic emission test in Crimean-Congo hemorrhagic fever. Int J Infect Dis 12: 162-165.

43. Javer AR, Elliott HF, Longridge NS (1998) Hantavirus infection: a possible cause of delayed sensorineural hearing loss. Otolaryngol Head Neck Surg 118: 697-701.

44. Steele NP, Myssiorek D (2006) West Nile virus induced vocal fold paralysis. Laryngoscope 116: 494-496.

45. Dunand VA, Hammer SM, Rossi R, Poulin M, Albrecht MA, Doweiko JP, DeGirolami PC, Coakley E, Piessens E, Wanke CA (1997) Parasitic sinusitis and otitis in patients infected with human immunodeficiency virus: report of five cases and review. Clin Infect Dis 25: 267-272.

46. Casero R, Laconte L, Fraenza L, Iglesias N, Quinteros Greco C, Villablanca M (2010) Recidivant laryngeal leishmaniasis: an unusual case in an immunocompetent patient treated with corticosteroids. Rev Argent Microbiol 42: 118-121.

47. Karimbil SK, Kumari S, Celine MI, Joy A (2010) A chronic mutilating rhinopathy with a delayed diagnosis of mucocutaneous leishmaniasis. Int J Dermatol 49: 426-429.

48. Prokopakis EP, Panagiotaki IE, Papadakis IA, Vardouniotis AS, Lagoudianakis GM, Velegrakis GA (2010) Immunocompromised patient with an ulcerated nasolabial skin lesion. BMJ 340: c1444.

49. Pau M, Atzori L, Aste N (2009) Two cases of primary endonasal leishmaniasis in Sardinia (Italy). Dermatol Online J 15: 5 .

50. Fsadni C, Fsadni P, Piscopo T, Mallia Azzopardi C (2007) Laryngeal leishmaniasis in Malta. J Infect 54: e61-63.

51. Diaz Sastre MA, Padilla Parrado M, Morales Puebla JM, Jimenez Antolin JA, Caro Garcia MA, Chacon Martinez J, Menendez Loras LM, Orradre Romeo JL (2007) [Laryngeal leishmaniasis]. An Otorrinolaringol Ibero Am 34: 17-25.

52. Grasa JM, Lorente J, Crego F, Naches S, Subirana FX, Calderon JR, Pollan C, Encarnacion LF, Quesada P (2000)
[Nasal leishmaniasis in an HIV-positive patient]. Acta Otorrinolaringol Esp 51: 169-173.

53. Cascio A, Antinori S, Campisi G, Mancuso S (2000) Oral leishmaniasis in an HIV-infected patient. Eur J Clin Microbiol Infect Dis 19: 651-653.

54. Antinori S, Cascio A, Parravicini C, Bianchi R, Corbellino M (2008) Leishmaniasis among organ transplant recipients. Lancet Infect Dis 8: 191-199.

55. Schroeder D, Foguena AK, Cometta A, Greub G, Cavassini M (2010) A 48-year-old man with laryngeal mass and vocal cord palsy. Clin Infect Dis 50: 1680-1631.

56. Richter J, Hanus I, Haussinger D, Loscher T, Harms G (2011) Mucosal Leishmania infantum infection. Parasitol Res 109: 959-962.

57. Shashy RG, Pinheiro D, Olsen KD (2006) Toxoplasmosis lymphadenitis presenting as a parotid mass: a report of 2 cases. Ear Nose Throat J 85: 666-668.

58. Mohamad I, Abdullah B, Salim R, Rajet KA, Naik VR (2010) Cryptococcocis: a rare fungal infection of the tongue. Southeast Asian J Trop Med Public Health 41: 1188-1191.

59. Butt AA, Carreon J (1997) Histoplasma capsulatum sinusitis J Clin Microbiol 35: 2649-2650.

60. Laccourreye O, Mirghani H, Brasnu D, Badoual C (2010) Imported acute and isolated glottic paracoccidioidomycosis. Ann Otol Rhinol Laryngol 119: 89-92.

61. Franco-Paredes C, Dismukes R, Nicolls D, Hidron A, Workowski K, Rodriguez-Morales A, Wilson M, Jones D, Manyang P, Kozarsky P (2007) Persistent and untreated tropical infectious diseases among Sudanese refugees in the United States. Am J Trop Med Hyg 77: 633-635.

\section{Corresponding author}

Prof. Alfonso Rodriguez-Morales

Faculty of Health Sciences, Universidad Tecnologica de Pereira

Pereira, Colombia

Phone: +573008847448

Email: arodriguezm@utp.edu.co

Conflict of interests: No conflict of interests is declared. 